\title{
Oxidation Behavior of Nickel Based Alloys in Supercritical Water Environment
}

\author{
FLORENTINA GALAN ${ }^{1}$, MARIAN CATALIN DUCU ${ }^{1}$, MANUELA FULGER ${ }^{2}$, \\ DENIS AURELIAN NEGREA ${ }^{1 *}$ \\ ${ }^{1}$ University of Pitesti, CRC\&D-Auto, 11 Doaga Str., 110440, Pitesti, Romania \\ ${ }^{2}$ Institute for Nuclear Research Pitesti, 1 Campului Str., 115400, Mioveni, Romania
}

\begin{abstract}
Corrosion resistance is a key performance factor for engineering materials used in the supercritical water-cooled reactors (SCWR). Choosing the materials with the best characteristics in the corrosive environment for SCWR, at high temperatures and pressures, is a real challenge for many researchers. Therefore, this paper aims to test two nickel-based alloys (Incoloy 800HT and Inconel 718) and to analyze the microstructures of the samples following exposure in a supercritical environment. Oxidation tests were performed at high temperature and pressure $\left(550^{\circ} \mathrm{C}, 25 \mathrm{MPa}\right)$ for up to 70 days. The samples were investigated using gravimetric corrosion test and scanning electron microscopy coupled with energy dispersive X-ray spectroscopy (SEM-EDX). The results obtained can be used in future research of the test protocol to identify alloys that could be used for SCWR components.
\end{abstract}

Keywords: SCWR, nickel based alloys, oxidation, gravimetric corrosion test, SEM-EDX

\section{Introduction}

The importance of developing new generations of nuclear power systems has led to the expansion of concepts for SCWR, these reactors will operate above the critical thermodynamic point of water $\left(\mathrm{T}_{\mathrm{c}}=\right.$ $647.096 \mathrm{~K}, \rho_{\mathrm{c}}=0.322 \mathrm{~g} \cdot \mathrm{cm}^{-3}$ and $\left.\mathrm{P}_{\mathrm{c}}=22.064 \mathrm{MPa}\right)$. SCWRs are satisfactory for advanced nuclear systems due to simplified plant design and higher thermal efficiency. Supercritical water (SCW) presents some serious challenges in material selection and chemistry control strategies to minimize corrosion and corrosion transport of the product. Nickel-based alloys are considered possible candidate materials for coating fuel tank and other components in the proposed supercritical water reactor, as they have been widely used in the design of nuclear power plants [1-4].

The characteristics of nickel-based alloys are given by resistance to high temperatures and hardness. It has good creep resistance, high surface stability and excellent resistance to oxidation and corrosion at high temperatures [5-8]. Thus, nickel based alloys are in high content in $\mathrm{Ni}, \mathrm{Cr}$, which could increase the oxidation and corrosion resistance at high temperatures [9-12]. In the literature, so far, the corrosion behaviors of Ni based alloys in supercritical water have been investigated [13-15]. In this study, the nickel-based alloys Incoloy 800HT and Inconel 718 were chosen, because they have the optimal balance of structural strength and corrosion resistance required for applications at high temperatures. The samples were exposed to supercritical water to study their behavior in the corrosive environment. These were investigated by gravimetry and scanning electron microscopy coupled with energy dispersive Xray spectroscopy.

\section{Materials and methods}

The materials selected for this study are two Ni based alloys - Incoloy 800HT and Inconel 718. The chemical composition of the studied materials is given in the table below (Table 1).

*email: denisnegrea@yahoo.com 
Table 1 Chemical composition of Incoloy 800HT and Inconel 718 (wt.\%)

\begin{tabular}{|c|c|c|c|c|c|c|c|c|c|c|c|c|c|c|}
\hline \multirow{2}{*}{$\begin{array}{c}\text { Alloy/ } \\
\text { chemical } \\
\text { elements }\end{array}$} & \multicolumn{10}{c|}{ Chemical elemental composition (wt.\%) } \\
\cline { 2 - 14 } & $\mathbf{C}$ & $\mathbf{A l}$ & $\mathbf{S i}$ & $\mathbf{M n}$ & $\mathbf{P}$ & $\mathbf{S}$ & $\mathbf{C r}$ & $\mathbf{N i}$ & $\mathbf{C u}$ & $\mathbf{M o}$ & $\mathbf{C o}$ & $\mathbf{T i}$ & $\mathbf{N b}$ & $\mathbf{F e}$ \\
\hline $\begin{array}{c}\text { Incoloy } \\
\mathbf{8 0 0 H T}\end{array}$ & 0.077 & 0.51 & 0.34 & 0.71 & - & $<0.001$ & $\mathbf{2 0 . 0 6}$ & $\mathbf{3 1 . 2 2}$ & 0.41 & - & 0.61 & 0.52 & - & 45.19 \\
\hline $\begin{array}{c}\text { Inconel } \\
\mathbf{7 1 8}\end{array}$ & 0.028 & 0.48 & 0.07 & 0.06 & 0.005 & $<0.001$ & $\mathbf{1 9 . 0 3}$ & $\mathbf{5 3 . 6 1}$ & 0.02 & 3.05 & 0.16 & 1.04 & 5.5 & 17.2 \\
\hline
\end{tabular}

The samples were cut in parallelepiped form from each material in the delivery state from Outokumpu Stainless AB Company. After cutting, the samples were mechanically polished with abrasive paper of different granulations (\# 600, \# 800, \# 1200) then with diamond paste to metallic luster, after which they were sonicated for $30 \mathrm{~min}$ in acetone. After sonication the samples were dried and then weighed to an analytical balance with an accuracy of $\pm 1 \times 10^{-4} \mathrm{~g}$.

The experiments were performed in a one-liter static autoclave in demineralized water at $550^{\circ} \mathrm{C}$ and $25 \mathrm{MPa}$ pressure for up to 70 days. The test solution had a $\mathrm{pH}$ of approximately 6.7 and after each inspection was replaced with fresh solution. Based on the initial values of mass and those obtained after autoclaving, the variation of the mass $\Delta \mathrm{W}$ reported to unit area $\left[\mathrm{mg} / \mathrm{dm}^{2}\right]$ and the variation of mass per unit area and exposure time $\mathrm{t}$ of the coupon, $\Delta \mathrm{W} / \mathrm{S} \mathrm{t}\left(\mathrm{mg} / \mathrm{dm}^{2} /\right.$ day), expressing the corrosion rate, were calculated.

After autoclaving tests, the samples were subjected to morphological/structural analysis. The sur face morphology and composition were analyzed using scanning electron microscope FESEM (Field Emission Scanning Electron Microscopy) Hitachi SU5000 provided with energy-dispersive X-ray spectroscopy (EDX) device.

\section{Results and discussions}

Following the oxidation experiment carried out at $550^{\circ} \mathrm{C}$ up to 70 days, the weight gain values were recorded every 10 days once, which are represented in the Figure 1. Trends are based on limited experimental data, as autoclave testing requires long testing times.

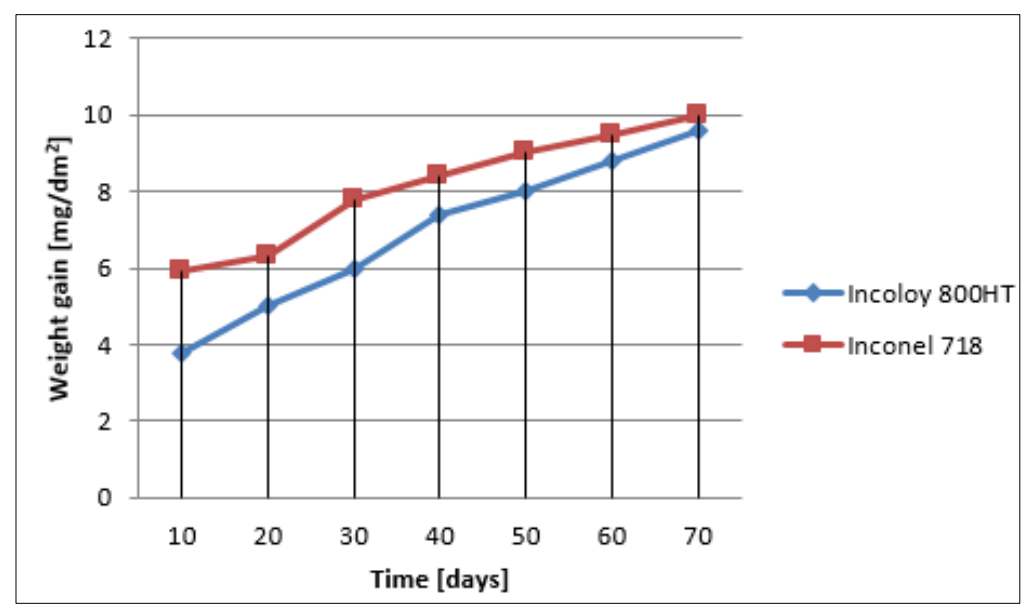

Figure 1. Weight gain depending on exposure time for Incoloy 800HT and Inconel 718 samples

Based on weighing the samples, the corrosion rate was calculated, corresponding to the analysis every 10 days once. The figure below (Figure 2) shows the graph of corrosion rate in aqueous environment, under the specific conditions of the primary circuit existing in the SCWR. 


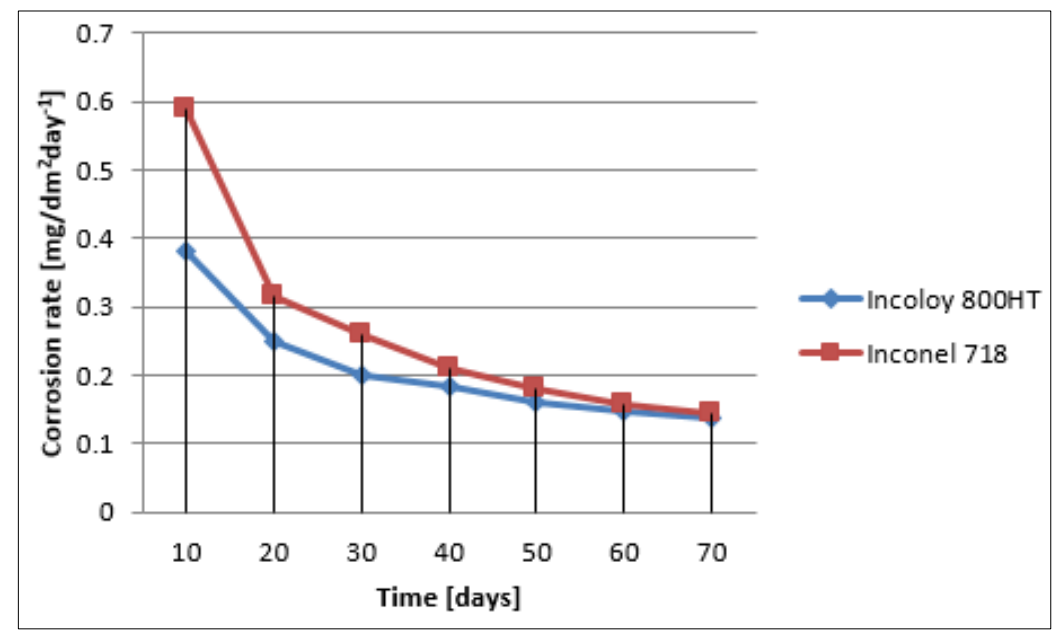

Figure 2. Corrosion rate $\left[\mathrm{mg} / \mathrm{dm}^{2} \mathrm{day}^{-1}\right]$ according to exposure time in supercritical water of the Incoloy 800HT and Inconel 718 samples

Based on the results from gravimetric analysis, it was found that exist a slight increasing in weight gain depending on the exposure time and the values of the corrosion rate represent a slight decreasing as a function of time. The measured data presented above, indicated that both alloys had comparatively weight gains, with slightly variations in the case of alloy 718 at the beginning of oxidation, behavior reflected obvious in evolution of corrosion rate.

The microstructure of Incoloy 800HT and Inconel 718 alloys was examined by scanning electron microscopy using backscattered electrons images after metallographic preparation by polish and oxalic acid chemical etching. The granulated images are shown in Figure 3 and Figure 4, which reveals the structural constituents of the as received samples and tested samples.

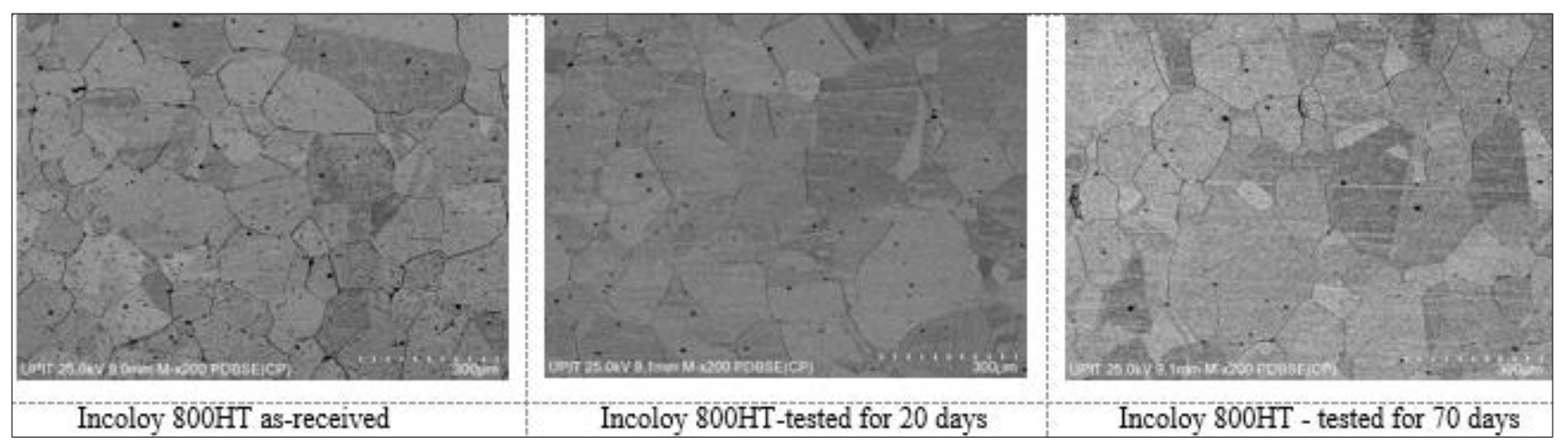

Figure 3. Grain structure Incoloy $800 \mathrm{HT}$ according to the test period $(200 \times$ magnification $)$, cross-sectional bulk images

The micrographs of the Incoloy $800 \mathrm{HT}$ alloy, obtained at 200x magnification, both on the standard sample (as received) and on the samples tested for 20 days respectively 70 days, indicated the grain magnification unchanged. 


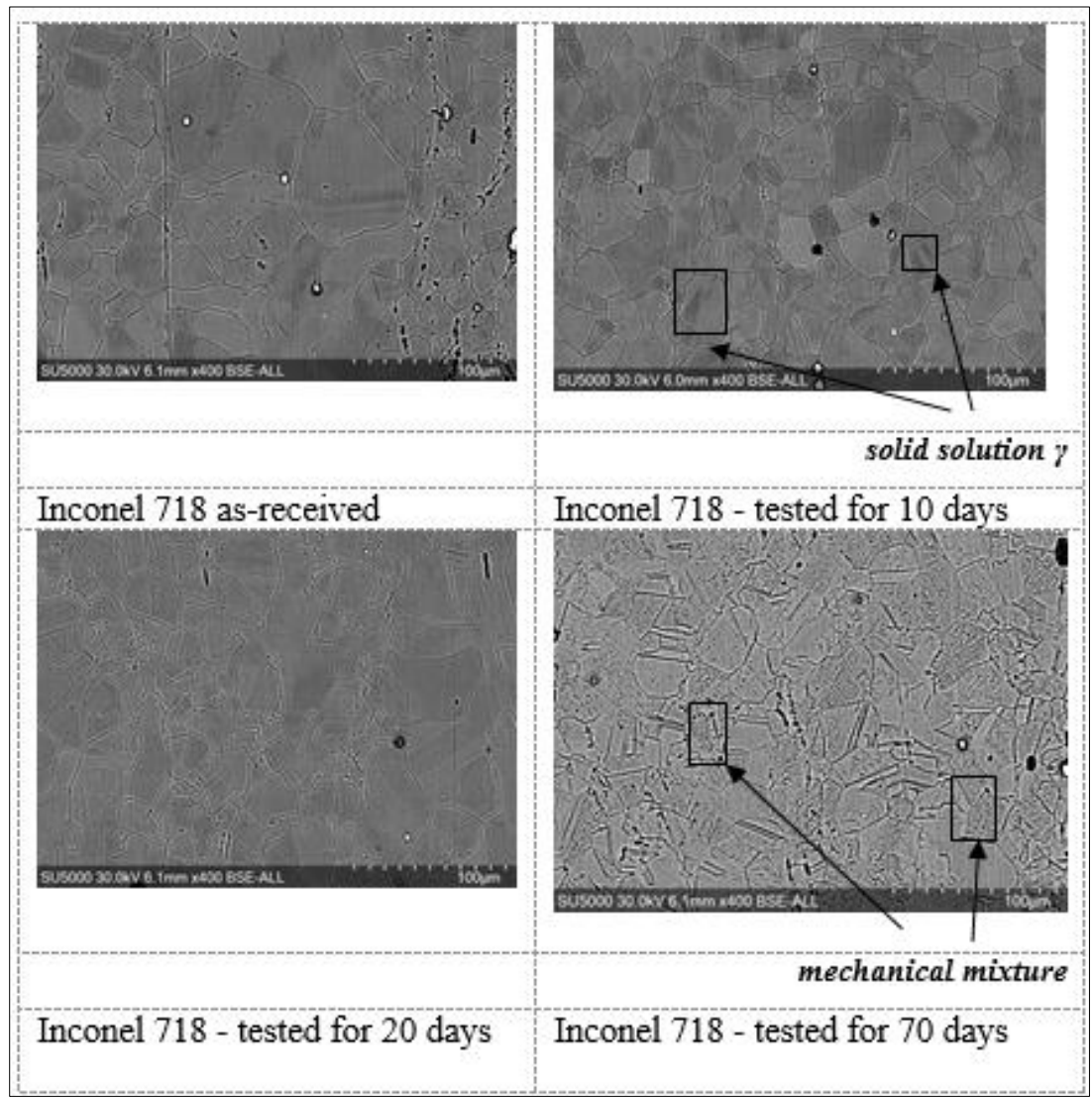

Figure 4. Grain structure Inconel 718 according to the test period $(400 \times$ magnification), cross-sectional bulk images by electron microscopy

In the case of the Inconel 718 alloy, on the standard sample (as received), have been observed equiaxial grains of solid solution $\alpha$. After testing in supercritical water for 10 days, the solid solution $\alpha$ predominates but dislocations appear which means that the solid solution $\gamma$ begins to form. After another 10 days of testing, the solid solution $\alpha$ is preserved, more solid solution $\gamma$ begins to appear and the formation of two-phase mechanical mixture can be identified. With the testing time increasing (70 days) the solid solution $\alpha$ decreased while the solid solution $\gamma$ and the mechanical mixture increased.

Figures 5 and 6 show images of the oxides developed on the Incoloy 800HT and Inconel 718 samples after a different exposure time and different magnifications obtained by scanning electron microscopy using secondary electrons. In Incoloy $800 \mathrm{HT}$ alloy, after 20 days, corrosion islands have been developed covering part of the surface.

The oxide particles have a similar pattern in all areas where it can be found. They have a random orientation and irregular/angular shapes. The growth of the surface oxide layer is the cause of the weight gain detected in these samples.
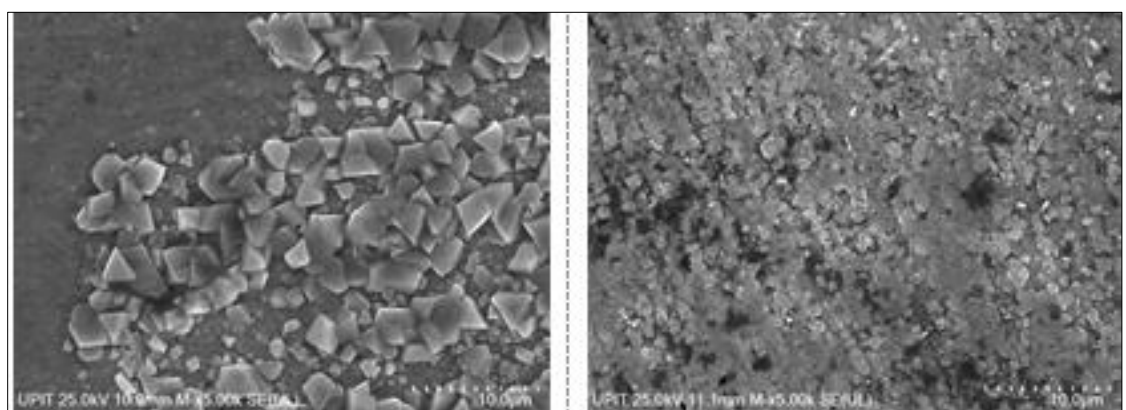

Figure 5. SEM surface images of Incoloy $800 \mathrm{HT}$ exposed in $\mathrm{SCW}\left(550{ }^{\circ} \mathrm{C}, 25 \mathrm{MPa}\right)$ for 20 and 70 days at $\mathrm{x} 5 \mathrm{k}$ magnification 
On the surface of Incoloy $800 \mathrm{HT}$, after 70 days, there are two types of areas with different colors. The morphology of the particles found in both areas is very similar, the uniform growth of the oxide grains is observed until they are connected together resulting in a compact layer.
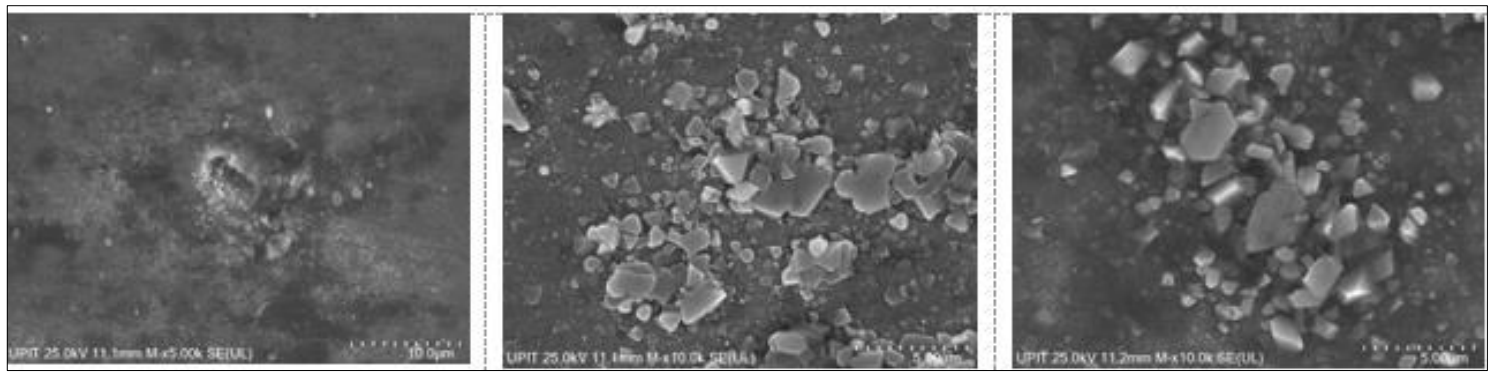

Figure 6. SEM surface images of Inconel 718 exposed in SCW $\left(550^{\circ} \mathrm{C}, 25 \mathrm{MPa}\right)$ for 10,20 and 70 days at $x 5 \mathrm{k}$ and $\mathrm{x} 10 \mathrm{~K}$ magnification

Figure 6 shows SEM images of Inconel 718 samples exposed to supercritical water at $550^{\circ} \mathrm{C}$ and $25 \mathrm{MPa}$ for 10, 20 and 70 days. The magnifications used vary between $\mathrm{x} 5 \mathrm{k}$ and $\mathrm{x} 10 \mathrm{k}$, depending on the characteristics of the surface to be analyzed. The polyhedral crystallites are arranged in the form of islands over a thin oxide scale, as in the case of the 800HT alloy, unless these crystallites are smaller.

SEM-EDX analysis was performed on the surface of Incoloy 800 HT exposed in SCW for 70 days. An electron image was acquired (Figure 7a) and two point scans have been performed in order to obtain the EDX spectra (Figure 7b) and the local chemical elemental composition (Table 2).
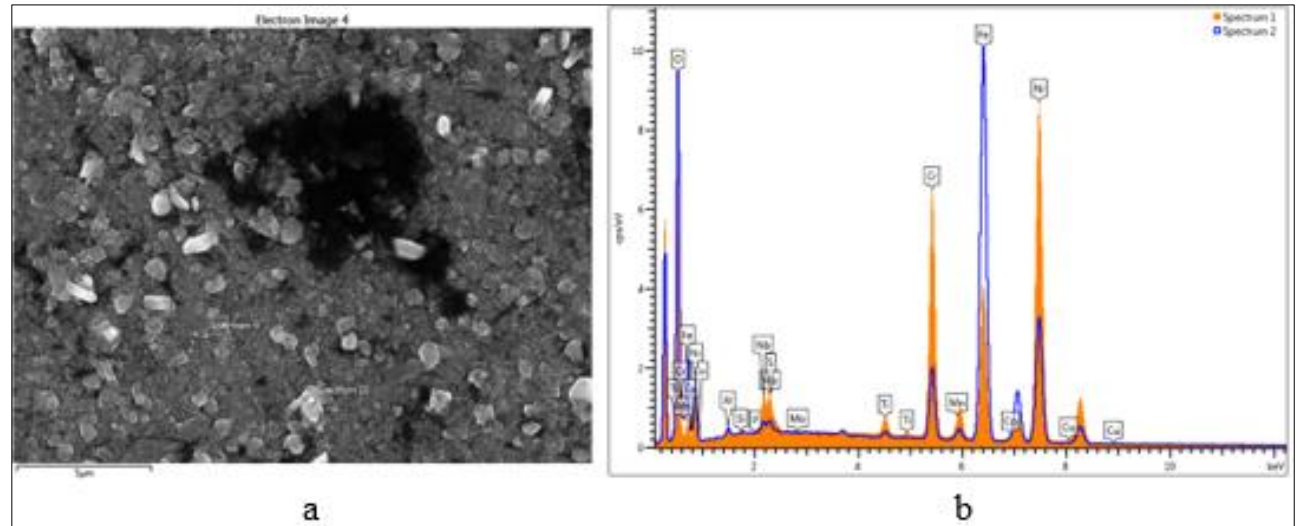

Figure 7. Surface electron image Incoloy $800 \mathrm{HT}$ sample tested for 70 days with indication of selected EDX point scans (a) and the obtained EDX superimposed spectra with elemental identification (b)

Table 2. EDX chemical elemental results from three point scans of Incoloy 800HT sample surface tested for 70 days

\begin{tabular}{|c|c|c|}
\hline \multirow{2}{*}{ Spectrum Label } & \multicolumn{2}{|c|}{ Elemental concentration (wt.\%) } \\
\cline { 2 - 3 } & Spectrum 9 & Spectrum 10 \\
\hline $\mathrm{O}$ & 17.94 & 29.13 \\
\hline $\mathrm{Al}$ & 2.38 & 2.50 \\
\hline $\mathrm{Si}$ & 0.50 & 0.44 \\
\hline $\mathrm{S}$ & 0.12 & 0.03 \\
\hline $\mathrm{Ti}$ & 0.41 & 0.39 \\
\hline $\mathrm{Cr}$ & 17.38 & 17.32 \\
\hline $\mathrm{Mn}$ & 0.69 & 1.04 \\
\hline $\mathrm{Fe}$ & 36.17 & 31.20 \\
\hline $\mathrm{Co}$ & 0.53 & 0.32 \\
\hline $\mathrm{Ni}$ & 23.38 & 17.31 \\
\hline $\mathrm{Cu}$ & 0.51 & 0.32 \\
\hline $\mathrm{Total}$ & 100.00 & 100.00 \\
\hline
\end{tabular}


The high percentages of iron and oxygen detected may suggest the presence of iron oxide $\left(\mathrm{Fe}_{3} \mathrm{O}_{4}\right)$, on the surface. The other oxide that appears in the sample tested for 70 days is believed to be chromium oxide $\left(\mathrm{Cr}_{2} \mathrm{O}_{3}\right)$ and /or spinelic oxide type $\mathrm{NiCr}_{2} \mathrm{O}_{4}$ as higher concentration of these elements have been detected.

Similar EDX analyzes were performed on Inconel 718 (Figure 8):
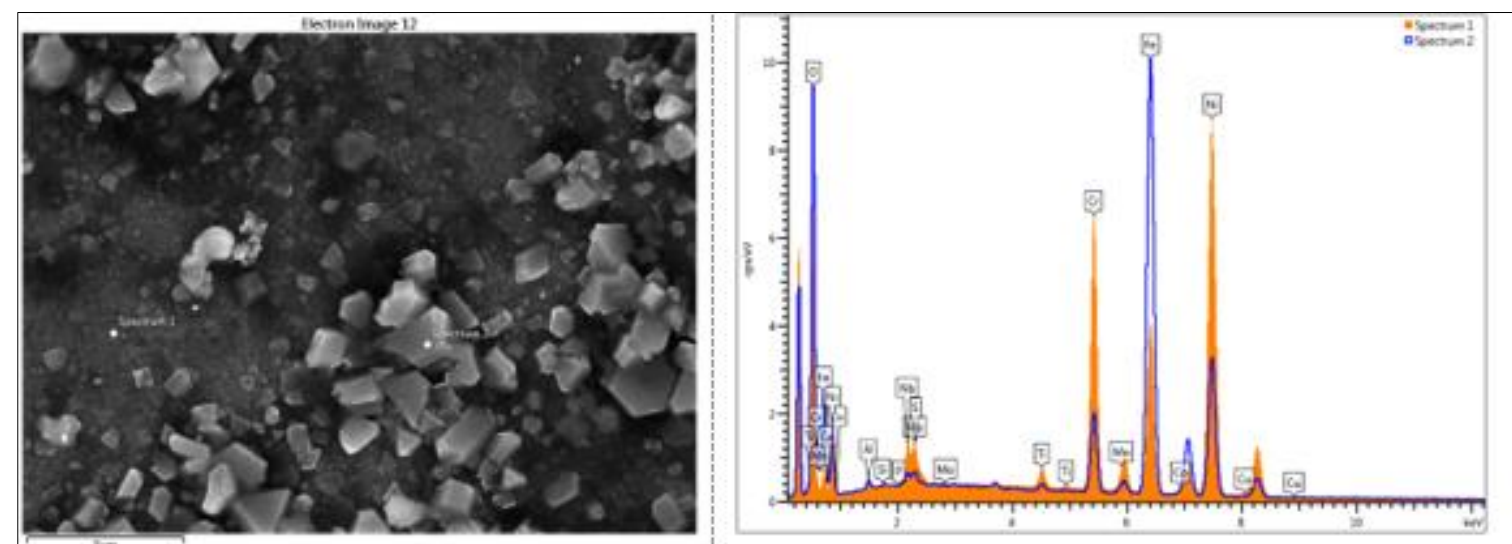

Figure 8. Surface electron image Inconel 718 sample tested for 70 days with indication of selected EDX point scans (a) and the obtained EDX superimposed spectra with elemental identification (b)

Table 3. EDX chemical elemental results from three point Scans of Inconel 718 sample surface tested for 70 days

\begin{tabular}{|c|c|c|}
\hline \multirow{2}{*}{ Spectrum Label } & \multicolumn{2}{|c|}{ Elemental concentration (wt.\%) } \\
\cline { 2 - 3 } & Spectrum 1 & Spectrum 2 \\
\hline $\mathrm{O}$ & 20.61 & 29.52 \\
\hline $\mathrm{Al}$ & 0.59 & 0.54 \\
\hline $\mathrm{Si}$ & 0.13 & 0.06 \\
\hline $\mathrm{P}$ & 0.00 & 0.00 \\
\hline $\mathrm{S}$ & 0.12 & 0.05 \\
\hline $\mathrm{Ti}$ & 0.85 & 0.35 \\
\hline $\mathrm{Cr}$ & 15.68 & 5.15 \\
\hline $\mathrm{Mn}$ & 0.10 & 0.28 \\
\hline $\mathrm{Fe}$ & 13.20 & 41.18 \\
\hline $\mathrm{Co}$ & 0.16 & 0.21 \\
\hline $\mathrm{Ni}$ & 42.81 & 20.35 \\
\hline $\mathrm{Cu}$ & 0.23 & 0.17 \\
\hline $\mathrm{Nb}$ & 3.50 & 1.20 \\
\hline $\mathrm{Mo}$ & 2.02 & 0.94 \\
\hline $\mathrm{Total}$ & 100.00 & 100.00 \\
\hline
\end{tabular}

Surface EDX analysis indicates high percentages of $\mathrm{O}, \mathrm{Fe}, \mathrm{Ni}, \mathrm{Cr}$. From the mapping it appears that $\mathrm{Fe}, \mathrm{Nb}$ and oxygen are concentrated inside the islands uniformly distributed in the selected area, while $\mathrm{Ni}$ and $\mathrm{Cr}$ are found in the vicinity of the islands. 


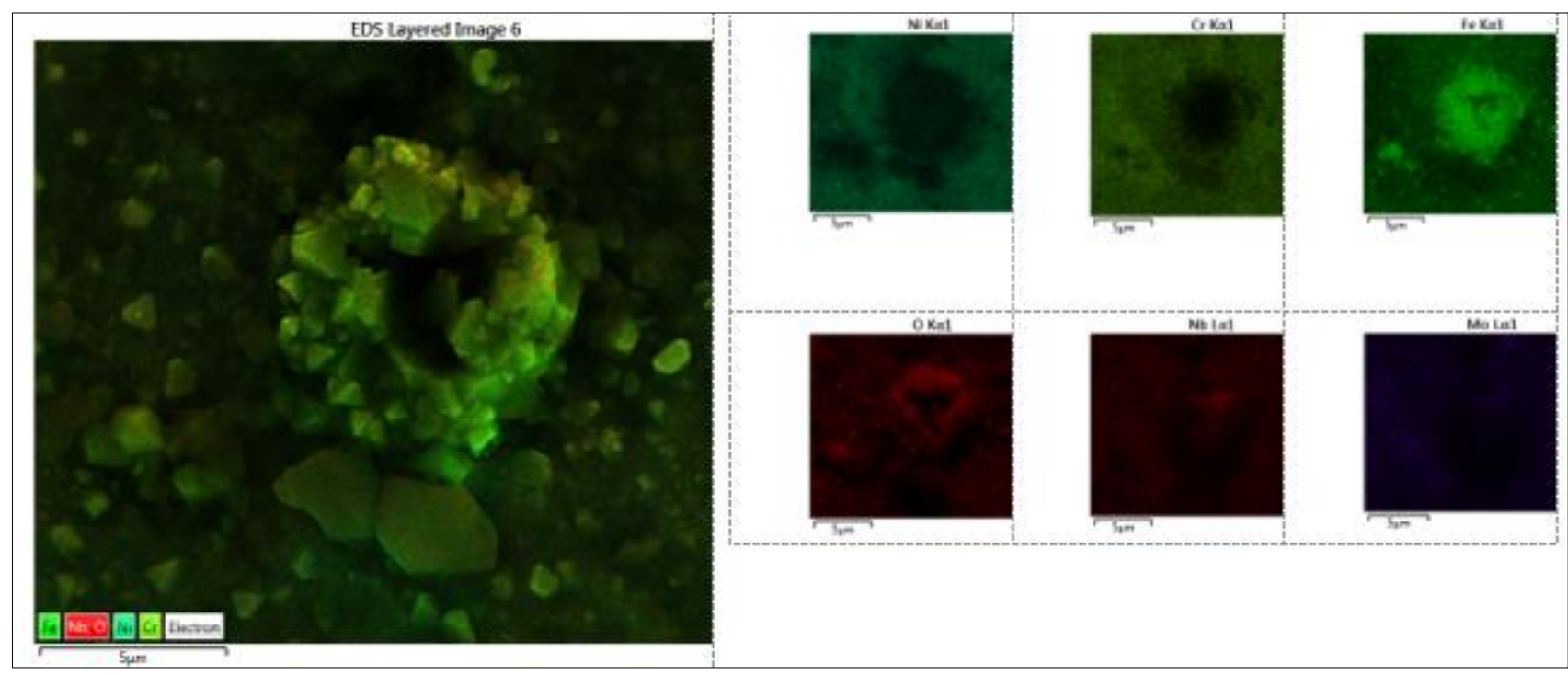

Figure 9. EDX maps of 718 alloy exposed up to 70 days in $\mathrm{SCW}$ at $550^{\circ} \mathrm{C}$

\section{Conclusions}

The SEM results on Incoloy $800 \mathrm{HT}$ after oxidation for 70 days in SCW shown two types of areas with different colors developed on the surface. The morphology of the particles found in both areas is very similar, the uniform growth of the oxide grains is observed until they are connected together resulting in a compact layer. The EDX analysis results indicated high percentages of iron and oxygen which suggest the presence of magnetite $\left(\mathrm{Fe}_{3} \mathrm{O}_{4}\right)$. The other oxides that appears on the surface of Incoloy $800 \mathrm{HT}$ tested for 70 days is believed to be chromium oxide $\left(\mathrm{Cr}_{2} \mathrm{O}_{3}\right)$ and /or spinelic oxide type $\mathrm{NiCr}_{2} \mathrm{O}_{4}$ as higher concentration of chromium was detected.

From the SEM analyzes of the Inconel 718 surface, it appears that the polyhedral crystallites are distributed in the form of islands over a thin oxide scale, as in the case of the 800HT alloy, unless these crystallites are smaller. Surface EDX analysis indicates high percentages of $\mathrm{O}, \mathrm{Fe}, \mathrm{Ni}, \mathrm{Cr}$ in the oxides developed as islands on the Inconel 718 samples surface. From the mapping it appears that $\mathrm{Fe}, \mathrm{Nb}$ and oxygen are concentrated inside of islands area while $\mathrm{Ni}$ and $\mathrm{Cr}$ are found in the vicinity.

From the gravimetric analysis we can conclude that both alloys had comparatively weight gains, with slightly variations in the case of alloy 718 at the beginning of oxidation, behavior reflected obvious in evolution of corrosion rate.

The results obtained can be used in future research of the test protocol to identify alloys that could be used for SCWR components.

\section{References}

1. AKHIANI, H., NEZAKAT, M., PENTTILÄ, S., SZPUNAR, J., The oxidation resistance of thermomechanically processed Incoloy $800 \mathrm{HT}$ in supercritical water, The Journal of Supercritical Fluids , 101, 2015, p. 150-160.

2. BEHNAMIAN, Y., MOSTAFAEI, A. et al., A comparative study of oxide scales grown on stainless steel and nickel-based superalloys in ultra-high temperature supercritical water at $800^{\circ} \mathrm{C}$, Corrosion Science, 106, 2016, p. 188-207.

3. YANG, J., WANG, S., TANG, X., WANG, Y., LI, Y., Effect of low oxygen concentration on the oxidation behavior of Ni-based alloys 625 and 825 in supercritical water, The Journal of Supercritical Fluids, 131, 2018, p. 1-10.

4. PAYET, M., MARCHETTI, L., TABARANT, M., CHEVALIER J.P., Corrosion mechanism of a Nibased alloy in supercritical water: Impact of surface plastic deformation, Corrosion Science, 100, 2015, p. 47-56. 
5. RODRIGUEZ, D., MERWIN, A., KARMIOL, Z., CHIDAMBARAM D., Surface chemistry and corrosion behavior of Inconel 625 and 718 in subcritical, supercritical, and ultrasupercritical water, Applied Surface Science, 40415, 2017, p. 443-451.

6. GUZONAS, D., PENTTILÄ, S., COOK, W., ZHENG, W., KANEDA J., The reproducibility of corrosion testing in supercritical water-Results of an international interlaboratory comparison exercise, Corrosion ScienceVolume, 106, 2016, p.147-156.

7. SUZAN, B., BINGJIE, X., XIAO,. H., SAMI, P., Oxidation Behaviour of Alloys 800H, 3033 and 304 in High-Temperature Supercritical Water, Oxidation of Metals, 89, 2018, p. 151-163.

8. FULGER, M., MIHALACHE, M., OHAI, D.,FULGER, ST., VALECA,.S.C, Analyses of oxide films grown on AISI 304L stainless steel and Incoloy 800HT exposed to supercritical water environment, J.Nuclear Mater., 415, 2011, p. 147-157.

9. KUANG, W., SONG, M., WAS, S.G., Insights into the stress corrosion cracking of solution annealed alloy 690 in simulated pressurized water reactor primary water under dynamic straining, Acta Materialia, 1511, 2018, p. 321-333.

10. CHOUDHRY, I. K., MAHBOUBI, S., BOTTON, A. G., KISH, R. J., SVISHCHEV, M. I., Corrosion of engineering materials in a supercritical water cooled reactor: Characterization of oxide scales on Alloy $800 \mathrm{H}$ and stainless steel 316. Corrosion Science, 100, 2015, p. 222-230.

11. TAN, L., ALLEN, T. R., YANG, Y., Corrosion behavior of alloy $800 \mathrm{H}$ (Fe-21Cr-32Ni) in supercritical water, Corros. Sci., 53, 2011, p. 703-711.

12. S. PENTTILÄ, I. BETOVA, M. BOJINOV, P. KINNUNEN, A. TOIVONEN, Oxidation model for construction materials in supercritical water - Estimation of kinetic and transport parameters, Corrosion Science, 100, 2015, p. 36-46.

13. LI, H. Y., WANG, Z. S., TANG, Y. X., XU, H. D., GUO, Y., ZHANG, J., QIAN, L. L., Effects of Sulfides on the Corrosion Behavior of Inconel 600 and Incoloy 825 in Supercritical Water, Oxid Met, 84, 2015, p. 509-526.

14. TANG, X., WANG, S., QIAN, L., LI, Y., LIN, Z., XU, D., Corrosion behavior of nickel base alloys, stainless steel and titanium alloy in supercritical water containing chloride, phosphate and oxygen. Chem Eng Res Des, 100, 2015, p. 530-541.

15. BSAT, S., HUANG, X., Corrosion behaviour of In625 in superheated steam at $800^{\circ}$ C. Corros Eng, Sci Technol, 51, 2016, p.321-328.

$\overline{\text { Manuscript received: } 25.05 .2020}$ 